\title{
Оксана Шевчук
}

кандидат юридичних наук, дочент, дочент кафедри конституиійного, адміністративного та фінансового права юридичного факультету Тернопільського національного економічного університету

\section{СУТНІСТЬ СТРАХУВАННЯ ЯК ІНСТИТУТУ ФІНАНСОВОГО ПРАВА}

Досліджено правову природу страхування як суспільного явища, щзо, з одного боку, виступає як елемент фінансової системи країни, з іншого, - як механізм захисту осіб від негативних наслідків певних непередбачуваних подій. Висвітлено саме фінансово-правовий аспект страхової діяльності.

Ключові слова: страхування, фінансово-правове регулювання страхової діяльності, страховий фонд, фінансово-правовий режим страхування, обов'язкове страхування, добровільне страхування.

\section{Шевчук О.}

\section{Сутность страхования как института финансового права}

Исследовано правовую природу страхования как общественного явления, что, с одной стороны, выступает как элемент финансовой системы страны, с другой - как механизм защиты лиц от негативных последствий определенных непредвиденных событий. Освещчено именно финансово-правовой аспект страховой деятельности.

Ключевые слова: страхование, финансово-правовое регулирование страховой деятельности, страховой фонд, финансово-правовой режим страхования, обязательное страхование, добровольное страхование.

\section{Shevchuk $O$.}

\section{The legal character of insurance as financial law snstitute}

The article is is devoted to we deal with investigation of the legal character of insurance, like social phenomenon, which on the one hand functions like the element of financial system of the country, and on the other hand like a mechanism of citizens defense from negative consequences of definite unforeseeable events.

Keywords: insurance; financially-legal adjusting of insurance activity; insurance fund; financially-legal mode of insurance; obligatory insurance; voluntarily insurance.

Постановка проблеми. Розвиток суспільства зумовлює необхідність більш повного соціального та економічного забезпечення безпеки особи. Важливим кроком для забезпечення створення безпечного простору для фізичних осіб, а також гарантованих соціально економічних передумов діяльності суб' єктів господарювання є перехід України на шлях ринкової економіки, який неможливий без існування всіх економіко-правових механізмів, що зумовлюють ефективність функціонування фінансово-кредитної системи країни. Україна знаходиться на стадії пошуку методів, адекватних новим умовам господарювання в економіці. Деякі інститути створені та плідно функціонують (наприклад, банківська система загалом), інші потребують реформування та вдосконалення.

3’ясування фінансово правової сутності страхування, його основної ідеї є особливо важливим питанням сьогодні - в період реформування економіки, зміни стереотипів мислення, розбудови в Україні нової правової держави.

Аналіз останніх досліджень і публікацій. Теоретичним підгрунтям дослідження були праці таких вчених, як: С. С. Алексєєв, Е. А. Алісов, Д. А. Бекерська, Л. К. Воронова, О. М. Горбунова, О. О. Дмитрик, М. В. Карасьова, Л. Л. Кінащук, М. П. Кучерявенко, Л. А. Мотильов, С. С. Осадець, В. К. Райхер, Л. А. Савченко, В. І. Серебровський, С. Д. Ципкін, Р. О. Халфіна, Н. І. Хімічева, О. І. Худяков, В. В. Шахов.

Метою статті є дослідження правової природи страхування як суспільного явища, що, 3 одного боку, виступає як елемент фінансової системи країни, з іншого, - як механізм захисту осіб від негативних наслідків певних непередбачуваних подій.

Виклад основного матеріалу дослідження. Страхування - широка, багатоаспектна правова, економічна та соціальна категорія. В наукових джерелах постійно зустрічається теза, що страхування важко піддається точному науковому осмисленню. Залишається вірною визначена раніше думка про те, що «до цього часу не вдалося досягти створення такого визначення, яке, з одного боку, не було б занадто вузьким (с) Оксана Шевчук, 2017 
Шевчук О.

Сутність страхування як інституту фінансового права

і обіймало всі види страхування, з іншого, - не було б занадто широким і не зачіпало своєю сферою явищ сторонніх» $[1,435-436]$.

Вирішення питання щодо визначення сутності категорії страхування полягає у розкритті всіх ознак, що притаманне цьому багатоаспектному явищу.

В енциклопедичному словнику «Економіка і страхування» страхування визначається як:

1) економічна категорія, тобто як сукупність форм та методів формування цільових грошових фондів та їх використання для відшкодування збитків, завданих різноманітними небажаними подіями (страховими випадками), а також для надання допомоги громадянам та (чи) їх сім'ям внаслідок настання певних подій в їхньому житті (дожиття, травми, інвалідності).

2) форма забезпечення зобов’язань у господарському і цивільно-правовому обігу, що реалізується через систему фінансової компенсації на випадок настання несприятливих обставин в обмін на переважно регулярну сплату невеликих грошових сум (страхових премій), що формують страховий фонд, який включається уповноваженою на те особою (страховиком) у прибуткові акти. [2, 146-148]

С. С. Осадець сформував своє особисте визначення поняття «страхування». На його думку, «страхування» - це економічні відносини, за яких страхувальник сплатою грошового внеску забезпечує собі чи третій особі у разі настання події, зумовленої договором або законом, суму виплати страховиком, який утримує певний обсяг відповідальності і для її забезпечення поповнює та ефективно розміщує резерви, здійснює превентивні заходи щодо зменшення ризику, у разі необхідності перестраховує частину останнього [3, с. 22-23].

Категорія «страхування» розглядається науковцями з різних точок зору, зокрема, вчені-економісти визначають страхування як сукупність особливих грошових перерозподільних відносин, пов’язаних 3 подоланням наслідків стихійного лиха та надзвичайних подій [4, с. 8; 5, с. 16], чи як відшкодування дії випадку через взаємність, організовану згідно з законом статистики. В юридичній літературі страхування розглядається як один із видів підприємницької чи господарської діяльності [6, с. 490], у тому числі через об’єднання окремих страхувальників, як договір, або як спосіб захисту майнових інтересів громадян в умовах ринкової економіки , у тому числі шляхом відшкодування збитків [5, с. 416].

Визначення страхування як системи особливих фінансових відносин між його учасниками 3 приводу формування цільових страхових фондів, за рахунок грошових вкладів фізичних і юридичних осіб, що призначений для відшкодування можливих непередбачених та інших збитків підприємств та організацій або надання грошової допомоги громадянам, розкриває суть страхування як економічної категорії.

При характеристиці страхування лише як виду підприємницької діяльності невисвітленим залишається порядок акумуляції грошових фондів, зобов'язання кожного з учасників у разі настання страхової події і, нарешті, саме поняття страхової події [7, с. 49].

Аналіз багатьох дефініцій, що визначають страхування, дозволяє встановити, що різні автори вбачають у страхуванні спосіб, форму, метод, регулятор, сукупність економічних відносин і т. ін., тому піддаючи аналізу цю інституцію, треба усвідомлювати багатоаспектність та системність цього явища.

Основний зміст страхування можна розкрити за умови характеристики основних його аспектів, а саме фінансового, соціального та правового.

В науковій літературі значної уваги приділено характеристиці страхування як соціально-економічної категорії. Домінуючою серед різних наукових позицій зору є та, за якою страхування розглядається як система економічних відносин, яка включає сукупність форм та методів формування цільових фондів грошових коштів та їх використання при різноманітних непередбачених несприятливих явищах. Л. І. Рейтман зазначав, що страхування являє собою «...сукупність особливих замкнутих перерозподільних відносин поміж його учасників з приводу формування за рахунок грошових внесків цільового страхового фонду, призначеного для відшкодування можливого надзвичайного та іншого збитку підприємствам й організаціям або для надання грошової допомоги громадянам». Науковець вказував на те, що страхування є не лише фінансовою, а й кредитною категорією [4, с. 15-23]. Безсумнівно, замкненість та перерозподільність уявляються важливими рисами страхування, які доводять фінансову природу даних відносин. П. Д. Біленчук, узагальнюючи характеристику страхування, зазначає, що «страхування - це система особливих грошових відносин ...; вид цивільно-правових відносин щодо захисту майнових інтересів громадян та юридичних осіб у разі настання певних подій, визначених договором страхування або чинним законодавством, за рахунок грошових фондів ...; форма організації централізованого страхового фонду за рахунок децентралізованих джерел» [8, с. 42]. 
Під економічним кутом зору страхування розглядають також вчені-економісти Ю. М. Журавльов та I. Г. Секерж. «Страхування - категорія економічна...», -зазначають вони, розкриваючи далі факультативні ознаки страхування.

Подібні погляди зустрічаються і в українській фінансово-правовій літературі. «Страхування є системою особливих грошових відносин, що займають проміжну ланку між фінансовими і кредитними відносинами», - зазначено у знаному в Україні підручнику з фінансового права [9, с. 230].

В. С. Бєлих та I. В. Кривошеєв розуміють під страхуванням «...сукупність врегульованих нормами права ... економічних відносин щодо формування (акумуляції) та використання (перерозподілу) грошових коштів із спеціального грошового фонду (із відповідного бюджету - при обов'язковому державному страхуванні) з метою страхової охорони майнових інтересів фізичних та юридичних осіб через відшкодування збитку, нанесеного страхувальнику (застрахованій особі) настанням страхового випадку або іншої заздалегідь передбаченої події в житті громадян».

Значна частина науковців визначають страхування як вид господарської діяльності. Ще в першій пол. XX ст. вчені-економісти намагалися уніфікувати визначення «страхування» як категорії економічної, і надавали своїм дефініціям деяких елементів, що притаманні страхуванню як одній з форм господарювання. Яскаравим прикладом є визначення: «Страхування це така господарська організація, яка усуває негативні наслідки випадкових непередбачуваних подій для майна певної особи таким шляхом, що воно розподіляє їх на ряд випадків, яким загрожували однакові небезпеки, але в дійсності не наступили» [10, с. 18].

Особливу позицію в галузі страхування, займає професор В. В. Шахов. У своїх працях вчений послідовно дотримується точки зору, згідно з якою страхування є відмінною від фінансів, економічною категорією. На його думку, «...грошове господарство» держави складають фінанси, кредит та страхування. Страхування має принципові відмінності від фінансів та кредиту. «Внесення страхових правовідносин до фінансової системи держави є обмеженням сфери дії страхування», - вважає науковець. [11, с. 7]. На підтвердження своєї позиції висуваються такі аргументи. «Якщо сутність фінансів пов'язана зі страховими відносинами в процесі створення та використання фондів грошових коштів, то до сутності страхування необхідно підходити під іншим кутом зору. Центральною ланкою у трактуванні сутності страхування, - зазначає В. В. Шахов, - $€$ замкнена розкладка збитку поміж зацікавленими учасниками такої розкладки та обов'язкова прив'язка до можливості настання страхового випадку... Використання коштів страхового фонду пов'язано 3 настанням та наслідками страхових випадків. Ця обставина абсолютно не характерна для фінансів». До того ж, як зазначає вчений, страхування може мати не лише грошову, але й натуральну форму і не потребує формування страхових фондів [11, с. 17]. Загальними рисами, що об'єднують страхування з фінансами та кредитом, є лише їх об’єктивний характер, а також єдність грошової форми вираження [11, с. 39].

Характеризуючи страхування як фінансово-правовий інститут, необхідно зазначити, що воно належить до складу фінансової системи України як окрема складова.

Страхування як фінансово-правовий інститут характеризується такими найважливішим ознаками, рисами та принципами:

1. Страхування являє собою фінансові економічні відносини, які є, по-перше, грошовими, по-друге, перерозподільчими, оскільки на їх основі відбувається вторинний розподіл національного доходу.

2. Майновою основою страхових відносин $є$ формування цільових страхових фондів грошових коштів. Це страховий резерв фінансових чи матеріальних засобів, який має виключно цільове призначення: покриття непередбачуваних витрат; відшкодування збитків потерпілим від страхових подій; вирівнювання добробуту за умов кон'юнктурних коливань.

3. Розподіл збитків на багатьох зобов'язаних осіб є чи не найважливішою ознакою страхування, за допомогою якої забезпечується здійснення страхових виплат в належному розмірі. Розкладка збитків має замкнутий характер, тому резерви страхових фондів витрачаються виключно для компенсації майнових втрат його учасників. Страхування засноване на догмі, що кількість страхувальників, які попали у страховий випадок, є значно меншою, ніж загальна кількість учасників, що регулярно сплачують страхові внески до страхового фонду.

4. Залежність страхових виплат від настання страхового випадку. В рамках цієї ознаки виявляється ризиковий характер страхування. Страховий ризик це ймовірність зазнати втрат очікуваної економічної (фінансової) користі або прямих збитків через появу непевної (випадкової) події, що стосується майнового інтересу членів суспільства.

5. Оскільки страховик зобов’язаний провести страхову виплату страхувальнику, зазвичай виділяють таку ознаку страхування, як зворотність мобілізованих до страхового фонду платежів. Кошти стра- 
Шевчук О.

Сутність страхування як інституту фінансового права

хового фонду після об’єднання їх у страховий фонд підлягають (за виключенням відрахувань за послуги страхової компанії) виплаті учасникам фонду.

6. Існування страхування зумовлене настанням страхового ризику. Така ознака, як залежність від реалізації страхового ризику, на думку деяких авторів, є причиною того, що «страхові відносини мають вірогідний характер». Вірогідний характер притаманний страховому ризику, а саме страхове правовідношення триває постійно протягом зазначеного у договорі страхування строку. Страховий ризик в системі державного обов'язкового страхування, на відміну від страхування добровільного, передбачений не договором, а законом.

Сутність будь-якого явища та предмета розкривається у його функціях. Е. А. Ровінский вважав, що страхуванню притаманні такі функції: основна функція - відшкодування збитку, що нанесений стихійними лихами та нещасними випадками, а також надання матеріальної допомоги постраждалим громадянам та їх сім'ям; функція охорони власності від руйнівної дії стихії й нещасних випадків; функція сприяння подальшому росту виробничих сил держави, розвитку всього народного господарства.

Автори підручника «Страхове право» В. С. Бєлих та I. В. Кривошеєв дають свою інтерпретацію функцій страхування. На їхню думку, економічний зміст страхування проявляється в сукупності таких функцій: а) акумулятивна функція, що передбачає збір грошових коштів у вигляді страхових внесків для формування спеціалізованого страхового фонду; б) компенсаційна (перерозподільна) функція, тобто відшкодування збитку та особисте майнове забезпечення громадян як плата за страховий ризик; в) охороннопопереджувальна функція - здійснюється у комплексі заходів, що спрямовані на забезпечення страхової охорони майна страхувальника або особистих майнових інтересів, а також на попередження страхового випадку та мінімізацію збитку.

Професор В. В. Шахов виділяє функції, які, на його думку, «...виражають економічну сутність страхування, вказують на суспільне призначення страхування як самостійної економічної категорії». Серед них визначаються такі функції: формування спеціалізованого страхового фонду грошових коштів; відшкодування збитку (компенсація) та особисте матеріальне забезпечення громадян; попередження та мінімізація збитку [11, с. 40].

Отже, страхуванню як фінансово-правовій категорії притаманні ті ж самі функції, що й фінансам, а саме розподільна та контрольна, але в певних, специфічних модифікаціях. Так, розподільча функція фінансів реалізується у страхових відносинах через такі елементи як попередження, відновлення та заощадження.

Попереджувальна (превентивна) функиія страхування реалізується у можливості страхових компаній вкладати кошти в забезпечення безпечного середовища для страхувальників, щоб попередити настання страхового випадку та виплати певної, зумовленої договором грошової суми. Цю функцію ще інколи називають ризиковою, оскільки страхова виплата завжди пов'язана 3 настанням якої-небудь ризикової події, реалізацією страхового ризику.

Контрольна функція як основна функція фінансів притаманна й страхуванню. Вона проявляється у тому, що страхові платежі, що акумулюються у страховий фонд, мають цільовий характер, використовуються у визначених законодавством випадках і обмеженим колом суб'єктів. Ця функція проявляється одночасно з розподільчою і виступає однією з підстав здійснення фінансового страхового контролю та нагляду у сфері страхування.

Страхування виконує ощчадну функцію, адже страхування використовується не лише як засіб забезпечення захисту не лише особистих та майнових втрат, але й самих грошових коштів, які вкладені у страхові фонди. Але не можна цю функцію страхування розглядати лише в контексті накопичення кощтів. Дійсно, як вірно зазначає В. В. Шахов, акумуляція грошових коштів у страхуванні здійснюється не тільки 3 метою заощадження (накопичення), як це відбувається у випадках прийому вкладів, наприклад, кредитними установами. [11, с. 20]. Серед запропонованих концепцій наукових поглядів перевага віддається третій групі. Відповідно, страхування виконує ряд таких функцій: попереджувальну, відновлювальну, ощадну, інвестиційну, контрольну. В рамках будь-якої з них здійснюється обіг грошових коштів, розподіл (перерозподіл) грошової форми вартості, оскільки страхування - специфічна частина фінансів суспільства.

Страхування виконує важливі функції держави у сфері іiї фінансової діяльності, що зумовлює його фінансово-правову належність. Недооцінка ролі страхування у цій сфері може призвести до небажаних наслідків та втрати важливого інвестиційного інструменту, що широко застосовується в усьому світі вже протягом століть.

Висновки. Таким чином, страхування як соціально-економічна та фінансова категорія - це сукупність економічних, фінансових, соціальних та правових відносин щодо формування цільових фондів гро- 
шових коштів, призначених для відшкодування збитків, завданих внаслідок виникнення певних страхових ризиків (природного, техногенного, соціального та іншого характеру), передбачених законом та (або) договором, шляхом перерозподілу суми збитків поміж учасників формування цих фондів. У фінансовій системі суспільства страхування виступає самостійною фінансовою категорією, а в системі фінансового права - самостійним правовим інститутом. 3 точки зору фінансового права, страхування це - сукупність фінансовоправових норм, що регулюють відносини із формування цільових фондів грошових коштів, призначених для відшкодування збитків, завданих внаслідок реалізації певних страхових ризиків (природного, техногенного соціального та іншого характеру), передбачених законом та (або) договором, шляхом розкладки суми збитків поміж учасників формування цих фондів. Фінансово-правові норми, що встановлюють вимоги до платоспроможності страховика, напрями використання коштів страхових фондів, контролю (нагляду) за фінансовою діяльністю страховиків - формують відповідний фінансово-правовий інститут.

\section{Список використаної літератури}

1. Мамедов А. А. Финансово-правовое регулирование страховой деятельности // А. А. Мамедов - М. : Юриспруденичи, 2004. - 144 с.

2. Ефимов С. Л. Экономика и страхование: энциклопедический словарь. - М. : Церих-Пэл, $1996 .-286$ с.

3. Осадецьь С. С.Страхування: підруч. / С. С. Осадецьь, Т. М. Артюх, В. Л. Бабко, Т. В. Бабко, А. В. Бушанський. - К. : КНЕУ, 2002. - 599 с.

4. Рейтман Л. И. Личное страхование при социилизме / Л. И. Рейтман - М. : Финансы и статистика, 1982. - 142 c.

5. Заруба О. Д. Страхова справа: підруч. // О. Д. Заруба - К. : Знання, 1998. - 254 с.

6. Гражданское право: учеб. / под. ред. А. П. Сергеева, Ю. К. Толстого. - М. : ПБЮЛ Л. В. Рожников, 2000. - T. 2. -856 c.

7. Блашук Т. В. Цивільно-правове регулювання особистого страхування: дис. ... канд. юрид. наук: 12.00.03 / Київ. наи. ун-т ім. Тараса Шевченка. - К., 2003. - 255 с.

8. Біленчук Д. П. Страхове право України / Д. П. Біленчук, П. Д. Біленчук, О. М. Залетів, Н. І. Клименко. - К. : Атіка, 1999. - 367 с.

9. Бекерська Д. А. та ін. Фінансове право: навч. посіб. / Д. А. Бекерська, Л. К. Воронова, І. Б. Заверуха, Н. К. Ісаєва [та ін.]; за ред. Л. К. Воронова - К. : Вентурі, 1998. - 383 с.

10. Вінник О. М. Господарські товариства і виробничі кооперативи: правове становище / О. М. Вінник К. : Знання, 2008. -308 c.

11. Шахов В. В. Введение в страхование/ В.В. Шахов. -[2-е изд]. - М. : Финансы и статистика, 2001. - 289 с.

\section{References}

1. Mamedov, A. A. (2004). Fynansovo-pravovoe rehulyrovanye strakhovoi deiatelnosty [Financial and legal regulation of insurance activity]. Moscow: Yurysprudentsyia [in Russian].

2. Efimov, S. L. (1996). Ekonomyka y strakhovanye [Economics and Insurance]. Moscow: Tserikh-ple [in Russian].

3. Osadets, S. S, Artyuk, T. M., Babko, V. L., Babko, T. V., Busansky, A. V. (2002). Strakhuvannia [Insurance]. Kyiv: KNEU [in Ukrainian].

4. Raytman, L. I. (1982). Lychnoe strakhovanye pry sotsyalyzme [Personal insurance under socialism]. Moscow: Finance and Statistics [in Russian].

5. Zaruba, O. D. (1998). Strakhova sprava [Insurance Case]. Kyiv: Znannia [in Ukrainian].

6. Sergeeva, A. P., Tolstoy, Yu. K. (Ed.). (2000). Hrazhdanskoe pravo [Civil law]. (Vols. 1-4). Moscow: PBIuL L. V. Rozhnykov [in Russian].

7. Blashchuk, T. V. (2003). Tsyvilno-pravove rehuliuvannia osobystoho strakhuvannia [Civil law regulation of personal insurance] . Kiev: nats Un-t them. Taras Shevchenko [in Ukrainian].

8. Bilenchuk, D. P., Bilenchuk, P. D., Zaletov, O. M., Klimenko, N. I. (1999). Strakhove pravo Ukrainy [Insurance Law of Ukraine]. Kiev: Atika [in Ukrainian].

9. Bekerskaya, D. A, Voronova, L. K., Zaverukha, I. B, Isaeva, N. K., etc. (1998). Finansove pravo [Financial law]. Kiev : Venturi [in Ukrainian].

10. Vinnik, O. M. (2008). Hospodarski tovarystva i vyrobnychi kooperatyvy: pravove stanovyshche [Economic partnerships and production cooperatives: legal status] Kyiv: Znannia [in Ukrainian].

11. Shakhov V. V. (2001). Vvedenye v strakhovanye [Introduction to insurance] Moscow: Finance and Statistics [in Russian].

Стаття надійшла до редакції 06.12.2017. 